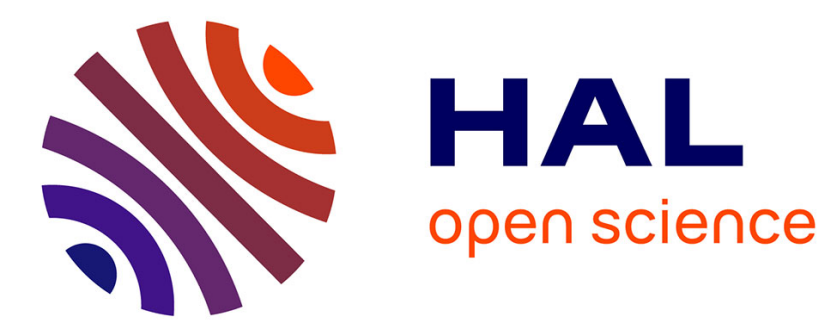

\title{
CHEMICAL EFFECTS OF THE 79Br(?, 2n) 77Br NUCLEAR REACTION IN K2ReBr6-K2ReCl6 MIXED CRYSTALS
}

H. Müller, S. Martin

\section{> To cite this version:}

H. Müller, S. Martin. CHEMICAL EFFECTS OF THE 79Br(?, 2n) 77Br NUCLEAR REACTION IN K2ReBr6-K2ReCl6 MIXED CRYSTALS. Journal de Physique Colloques, 1976, 37 (C7), pp.C7540-C7-540. 10.1051/jphyscol:19767124 . jpa-00216847

\section{HAL Id: jpa-00216847 https://hal.science/jpa-00216847}

Submitted on 1 Jan 1976

HAL is a multi-disciplinary open access archive for the deposit and dissemination of scientific research documents, whether they are published or not. The documents may come from teaching and research institutions in France or abroad, or from public or private research centers.
L'archive ouverte pluridisciplinaire HAL, est destinée au dépôt et à la diffusion de documents scientifiques de niveau recherche, publiés ou non, émanant des établissements d'enseignement et de recherche français ou étrangers, des laboratoires publics ou privés. 


\title{
CHEMICAL EFFECTS OF THE ${ }^{79} \mathrm{Br}(\gamma, 2 \mathrm{n}){ }^{77} \mathrm{Br}$ NUCLEAR REACTION IN $\mathrm{K}_{2} \operatorname{ReBr}_{6}-\mathrm{K}_{2} \operatorname{ReCl}_{6}$ MIXED CRYSTALS
}

\author{
H. MÜLLER and S. MARTIN \\ Chemical Laboratory, University Freiburg D-7800 Freiburg,
} Albertstr. 21, FRG

\begin{abstract}
In continuation of investigations of the chemical fate of $(n, \gamma)$ and $(\gamma, n)$ produced $\mathrm{Re}$ recoil atoms in $\mathrm{K}_{2} \mathrm{ReBr}_{6}-\mathrm{K}_{2} \mathrm{SnCl}_{6}[1,2]$ and $\mathrm{K}_{2} \mathrm{ReBr}_{6}-\mathrm{K}_{2} \mathrm{OsCl}_{6}$ [3] mixed crystals and IT and $(n, \gamma)$ produced $\mathrm{Br}$ recoil atoms in $\mathrm{K}_{2} \mathrm{ReBr}_{6}-\mathrm{K}_{2} \mathrm{SnCl}_{6}$ [4] and $\mathrm{K}_{2} \mathrm{ReBr}_{6}-\mathrm{K}_{2} \mathrm{ReCl}_{6}$ [5] mixed crystals we have investigated recently the chemical effects of ${ }^{77} \mathrm{Br}$ recoil atoms in the $\mathrm{K}_{2} \mathrm{ReBr}_{6^{-}}$ $\mathrm{K}_{2} \mathrm{ReCl}_{6}$ system activated by the nuclear reaction ${ }^{79} \mathrm{Br}(\gamma, 2 n){ }^{77} \mathrm{Br}$. By using ion exchange column chromatography as a new method of separation of the mixed $\mathrm{Re}^{77} \mathrm{BrBr}_{5-n} \mathrm{Cl}_{n}^{2-}$ species larger amounts of the irradiated material could be separated following the dissolution. The yield of $\mathrm{Re}^{77} \mathrm{BrBr}_{5}^{2-}$ increases, the yield of $\mathrm{Re}^{77} \mathrm{BrCl}_{5}^{2-}$ decreases significantly with increasing $\mathrm{K}_{2} \mathrm{ReBr}_{6}$ concentration, all the other mixed hexabromochlororhenates and the free bromide-(77 $\mathrm{Br})$ are only little dependent of the mixed crystal composition at least at concentrations below $50 \mathrm{~mol}-\%$ $\mathrm{K}_{2} \operatorname{ReBr}_{6}$. For zero $\mathrm{K}_{2} \operatorname{ReBr}_{6}$ content we obtained by extrapolation :

$\begin{array}{lr}{ }^{77} \mathrm{Br}^{-} & 16 \% \\ \operatorname{Re}^{77} \mathrm{BrBr}_{5}^{2-} & 3 \% \\ \operatorname{Re}^{77} \mathrm{BrBr}_{4} \mathrm{Cl}^{2-} & 5 \% \\ \operatorname{Re}^{77} \mathrm{BrBr}_{3} \mathrm{Cl}_{2}^{2-} & 5 \% \\ \operatorname{Re}^{77} \mathrm{BrBr}_{2} \mathrm{Cl}_{3}^{2-} & 6 \% \\ \operatorname{Re}^{77} \mathrm{BrBrCl}_{4}^{2-} & 16 \% \\ \operatorname{Re}^{77} \mathrm{BrCl}_{5}^{2-} & 49 \%\end{array}$

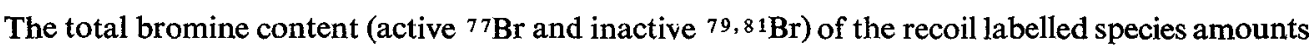
to $31 \%$ at zero $\mathrm{K}_{2} \operatorname{ReBr}_{6}$ concentration clearly indicating that on the average two bromide ligands (one of them being ${ }^{77} \mathrm{Br}$, the other inactive) of the original six survive the nuclear process and are still bonded to their original Re central atom. Especially the appearance of the more intimately mixed species cannot be explained by models discussed hitherto in the literature [6] (billiard ball impact, ligand vacancy exchange followed by combination [7], hot spot reaction). We propose here a new mechanism which we want to call the Inverse Cage Effect. Following this model $\mathrm{Br}$ recoil atoms that are directed towards the central atom transfer their kinetic energy via the central atom to all or part of the other ligands which are driven in the surrounding lattice. The newly formed yacancies are then filled by halide ions from the environment including the ligands just pushed away.

The experimental results may be summarized as follows : Besides a very small yield of primary retention ( $\left.\mathrm{Re}^{77} \mathrm{BrBr}_{5}^{2-}\right)$ one third of the recoil bromine atoms react following the inverse cage effect, two third are caught as interstitials $\left({ }^{77} \mathrm{Br}^{-}\right)$or undergo simple displacements $\left(\mathrm{Re}^{77} \mathrm{BrCl}_{5}^{2-}\right)$.

The recoil energy of the ${ }^{77} \mathrm{Br}$ is estimated to be not larger than ca. $1 \mathrm{keV}$. This suggests that the nuclear reaction ${ }^{79} \mathrm{Br}(y, 2 n) 77 \mathrm{Br}$ is far from a compound nuclear mechanism.
\end{abstract}

\section{References}

[1] MÜLLER, H., J. Inorg. Nucl. Chem. 27 (1965) 1745.

[2] MÜLleR, H., J. Inorg. Nucl. Chem. 31 (1969) 1579.

[3] MülleR, H., J. Inorg. Nucl. Chem. 29 (1967) 2167.

[4] Müller, H., Cramer, D., Radiochim. Acta 14 (1970) 78.
[5] MÜller, H., MartiN, S., Inorg. Nucl. Chem. Lett. 5(1969) 761.

[6] MÜllek, H., Angew. Chem. 79 (1967) 128 ; Angew. Chem. Int. Edit. 6 (1967) 133.

[7] Rössler, K., Otterbach, J., Stöcklin, G., J. Phys. Chem. 76 (1972) 2499.

\section{DISCUSSION}

H. Ackermann. - What has been your experimental procedure?

M. MüLLER. - The experimental methods are described in Z. Anorg. Allg. Chem. 321 (1963) 124 ;
336 (1965) 24 ; J. Inorg. Nucl. Chem. 27 (1965) 1745 ; Z. Analyt. Chem. 247 (1969) 145.

The ${ }^{77} \mathrm{Br}$ activity has been determined using the 239 and $520 \mathrm{keV}$ gamma lines measured with a $\mathrm{Ge}(\mathrm{Li})$ detector-multi channel analyser system. 